\title{
Ontario: Two Trees Planted For Each One Cut?
}

by

C.A. Benson ${ }^{1}$

\section{Introduction}

The Charter for Ontario, as put forth by the Progressive Conservatives in 1977, included the statement, "A commitment to replacing at least two trees for every one harvested henceforth in Ontario, and to regenerating every acre harvested." Whether the politicians meant actual planting or any type of regeneration is not clear. The statement may have reflected a political inability to understand the situation. In an effort to challenge the Conservatives, the opposition parties interpreted the statement to mean the planting of two trees for each one cut. Certainly, the prospect of calculating the number of trees cut in Ontario per year would cause some technical difficulties. However, the closing part of the statement, "to regenerating every acre harvested," is clear and practical to measure and relate to. In addition, the Ontario Cabinet approved a forest production policy in 1972 that was aiming for an allowable cut of 26 million $\mathrm{m}^{3}$ by the year 2020 . The forest production policy option compared five levels of management (Table 1). The production level of 26 million $\mathrm{m}^{3}$, between levels 3 and 4, was chosen as the target for 2020 (OMNR, 1972).

Reed (1980a) indicated that expenditures on forest management in 1979 increased by $37 \%$ over those of 1977 , although the public spending declined from $5-1 / 2$ cents to 5 cents per dollar of revenue. Consequently, it is of interest to examine the actual regeneration effort over the last few years to see if the various targets have been met and if an increase in spending has augmented results.

\section{History}

Regeneration data (Table 2) indicate that the Ontario Ministry of Natural Resources (OMNR) has been able to keep pace and even exceed planting the number of hectares requiring regeneration treatment, but has not replanted the total cutover area (Table 3). The percent of total cutover receiving artificial regeneration treatment has not increased over the past twelve years.

One can also note that from $1977 / 78$ to the present, a reduction has occurred of the percentage of area requiring regeneration treatment as compared to the total cutover area (Table 2). An upswing from 9 to $19 \%$ (7 to 15 thousand hectares) of patented land treated is evident in 1979/80.
In order to meet the production policy target of 26 million $m^{3}$, it would be necessary to rely on the natural regeneration of 53 thousand hectares in addition to artificially regenerating 158 thousand hectares on a land base of approximately 19 million hectares. The OMNR devised an implementation schedule in 1974 to reach this target level (OMNR, 1974). From 1975/76 on, the Ministry has been falling behind its implementation schedule (Table 3 ).

\section{Implications}

One obvious implication is that the government must increase its efforts if it is to achieve the "regenerating of every acre harvested". The average 73 thousand hectares regenerated over the last seven years represents $38 \%$ of the total cutover area (Table 2). The $38 \%$ regenerated artificially plus the $30 \%$ of the area regenerated naturally leaves $32 \%$ of the total cutover that is not treated. Of the $32 \%$ not treated, $10 \%$ required treatment, but did not receive it.

A more insidious implication concerns the amount of area available on which to obtain regeneration in Ontario. The average percentage of cutover land that was suitable for natural or assisted regeneration from 1973/74 ro 1979/80 totals $78 \%(30+48)$. When this figure is applied to the 43 million hectares ot total productive forest land in Ontario, an estimated 33 million are suitable for regeneration. The present forest production policy depends on a base of approximately 14 million hectares for artificial regeneration and another 5 million hectares of natural regeneration for a total of 19 million hectares. Therefore, a surplus of 14 million hectares is potentially available for regeneration. If the $1979 / 80$ percentages for naturally regenerated $(31 \%)$ and areas requiring regeneration (38\%) are applied in the same manner, the surplus is reduced to 11 million hectares. However, it is expected that the total productive forest land base will be reduced from 43 to 25 million hectares (Reed, 1980b). This leaves a surplus of 6 million hectares more than required by the production policy, if the land extracted for uses such as parks, wilderness areas, utilities, wildlife, agriculture, roads and aesthetics does not include the forest area suitable for natural and assisted regeneration. If these extracted lands do contain such areas the surplus would be reduced. The surplus would be reduced further if losses from fire and insects are included. Not all productive forest land area is

Table 1. Summary of the forest production policy in Ontario

\begin{tabular}{|c|c|c|c|c|c|c|}
\hline Policy no. & $\begin{array}{l}\text { Area treated } \\
\text { yearly (ha.) }\end{array}$ & $\begin{array}{l}\text { Rotation yield } \\
\text { ( } \mathrm{m}^{3} / \mathrm{ha} \text {.) }\end{array}$ & $\begin{array}{c}\text { Area regenerated } \\
\text { naturally yearly } \\
\text { (ha.) }\end{array}$ & $\begin{array}{l}\text { Rotation yield } \\
\text { (m³a.) }\end{array}$ & $\begin{array}{l}\text { Estimated harvest } \\
\text { by } 2020\left(\mathrm{~m}^{3} \times 10^{6}\right)\end{array}$ & $\begin{array}{c}\text { Land base } \\
\text { required } \\
\left(\text { ha. } \times 10^{6}\right)\end{array}$ \\
\hline 1 & - & - & 52,600 & 70 & 3.7 & 5 \\
\hline 3 & 99,600 & 140 & 52,600 & 70 & 17.6 & 14 \\
\hline Selected & & & & & & 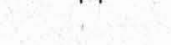 \\
\hline Level & 158,000 & 140 & 52,600 & 70 & 25.8 & 19 \\
\hline
\end{tabular}

NOTE: The yield at rotation for treated areas is expected to increase to $140 \mathrm{~m}^{3} / \mathrm{ha}$. as a result of more intensive management. Area treated yearly is the area requiring regeneration treatment.

${ }_{1}$ School of Forestry, Lakehead University 


\begin{tabular}{|c|c|c|c|c|c|c|c|}
\hline $\begin{array}{l}\text { Fiscal } \\
\text { year }\end{array}$ & $\begin{array}{c}\text { Total } \\
\text { cutover }\end{array}$ & $\begin{array}{l}\text { Area not avail. } \\
\text { for regen. treat. }\end{array}$ & $\begin{array}{l}\text { Area regen. } \\
\text { naturally }\end{array}$ & $\begin{array}{l}\text { Area req. } \\
\text { regen. } \\
\text { treatment }\end{array}$ & $\begin{array}{l}\text { Crown land } \\
\text { regenerated }\end{array}$ & $\begin{array}{l}\text { Patented } \\
\text { Land } \\
\text { regenerated }\end{array}$ & $\begin{array}{l}\text { Total land } \\
\text { regenerated }\end{array}$ \\
\hline \multicolumn{5}{|c|}{$\begin{array}{l}1,000 \text { 's hectares } \\
\text { (\% of total cutover) }\end{array}$} & \multicolumn{3}{|c|}{$\begin{array}{c}1,000 \text { 's hectares } \\
(\% \text { of total land regenerated })\end{array}$} \\
\hline 1979/80 & 219 & $\begin{array}{c}68 \\
(31)\end{array}$ & $\begin{array}{c}69 \\
(31)\end{array}$ & $\begin{array}{c}81 \\
(38)\end{array}$ & $\begin{array}{l}65 \\
(81)\end{array}$ & $\begin{array}{c}15 \\
(19)\end{array}$ & 80 \\
\hline $1978 / 79$ & 195 & $\begin{array}{l}62 \\
(32)\end{array}$ & $\begin{array}{l}57 \\
(29)\end{array}$ & $\begin{array}{l}76 \\
(39)\end{array}$ & $\begin{array}{l}71 \\
(91)\end{array}$ & $\begin{array}{l}7 \\
(9)\end{array}$ & 78 \\
\hline $1977 / 78$ & 188 & $\begin{array}{c}66 \\
(35)\end{array}$ & $\begin{array}{l}56 \\
(30)\end{array}$ & $\begin{array}{c}66 \\
(35)\end{array}$ & $\begin{array}{l}72 \\
(90)\end{array}$ & $\begin{array}{c}8 \\
(10)\end{array}$ & 80 \\
\hline $1976 / 77$ & 157 & $\begin{array}{l}25 \\
(16)\end{array}$ & $\begin{array}{c}41 \\
(26)\end{array}$ & $\begin{array}{c}91 \\
(58)\end{array}$ & $\begin{array}{c}65 \\
(90)\end{array}$ & $\begin{array}{c}7 \\
(10)\end{array}$ & 72 \\
\hline $1975 / 76$ & 197 & $\begin{array}{l}40 \\
(20)\end{array}$ & $\begin{array}{l}50 \\
(25)\end{array}$ & $\begin{array}{l}107 \\
(54)\end{array}$ & $\begin{array}{l}63 \\
(90)\end{array}$ & $\begin{array}{c}7 \\
(10)\end{array}$ & 70 \\
\hline $1974 / 75$ & 193 & (12) & $\begin{array}{l}62 \\
(32)\end{array}$ & $\begin{array}{l}108 \\
(56)\end{array}$ & $\begin{array}{l}67 \\
(90)\end{array}$ & $\begin{array}{c}7 \\
(10)\end{array}$ & 74 \\
\hline $1973 / 74$ & 192 & $\begin{array}{l}13 \\
(7)\end{array}$ & $\begin{array}{l}69 \\
(36)\end{array}$ & $\begin{array}{l}110 \\
(57)\end{array}$ & $\begin{array}{l}54 \\
(88)\end{array}$ & $\begin{array}{c}7 \\
(10)\end{array}$ & 61 \\
\hline Average & 191 & $\begin{array}{c}42 \\
(22)\end{array}$ & $\begin{array}{l}57 \\
(30)\end{array}$ & $\begin{array}{c}92 \\
(48)\end{array}$ & $\begin{array}{c}65 \\
(89)\end{array}$ & $\begin{array}{c}8 \\
(11)\end{array}$ & 73 \\
\hline \multicolumn{2}{|c|}{$\begin{array}{l}\text { Production Policy } \\
\text { Target for } 2020 \text { AD }\end{array}$} & & 52 & & & & 158 \\
\hline
\end{tabular}

Source: Hansard 1980, Statistics, various years.

Table 3. Comparison of cutover acres to regenerated area and production policy target in Ontario - 1968/69 to $1979 / 80$.

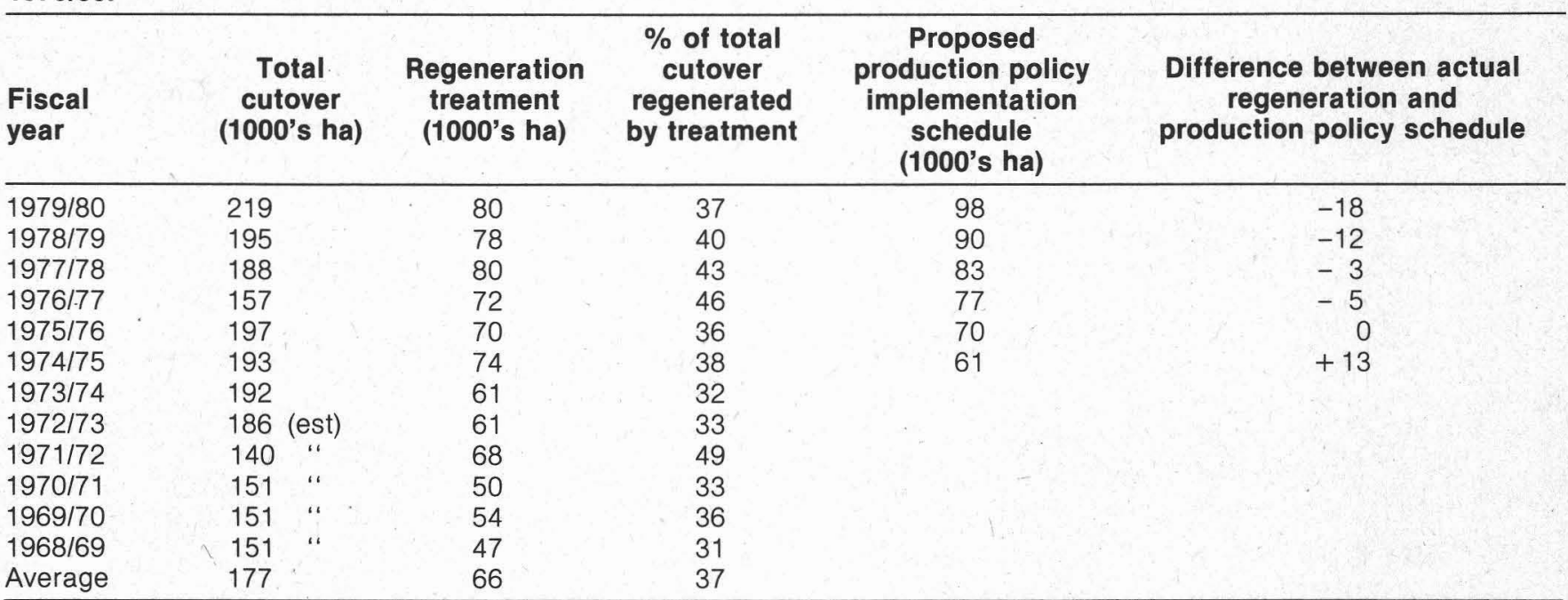

Note: Regeneration treatment from 1968 to $1972 / 73$ includes Crown land only. From 1973/74 to 1979/80 Crown land and Patented land are included.

located prior to cutting, (OMNR, 1980a), thus it is conceivable that the above extractions will include land needed for regeneration.

Recent Strategic Land Use Plans for the Northeastern and Northwestern Ontario $(1980 \mathrm{a}, \mathrm{b})$ indicate that the production policy will have to increase to 34 million $\mathrm{m}^{3}$ from 25.8 million $\mathrm{m}^{3}$ to meet the expected demand for wood in the next 20 years. This increase in the production target will reduce the theoretical surplus of production forest land to 1 million hectares. This surplus may not exist if it is set aside for other uses. A productive land survey as stressed by Armson (1976), is necessary to determine if a productive land base of 24 million hectares is available for regenerating at the rate of 217 thousand hectare per year.

Another problem is that the area available for regenerating conifers will probably not increase. Reed (1980b) maintains that the allowable cut of conifers is being fully utilized. The hardwood cut may be increased (Reed, 1978), but these areas will be difficult to regenerate to con- ifer. Future harvest plans indicate that $75 \%$ of the expected harvest will be conifers (OMNR, 1980a, b), therefore, the majority of the 158 thousand hectares will need to be regenerated to conifers. In order to achieve the present production target of artificially regenerating 158 thousand hectares yearly, it will be necessary to extend regeneration into the backlog areas. This enhances the problem as "detailed information (on backlog) is unavailable prior to the approval by cabinet of the forest production policy in 1972". (Hansard, 1979). Thus, the location and amount of backlog is not known.

Expenditures on silviculture in $1979 / 80$, excluding permanent staff and nursery stock costs, were approximately $\$ 15$ million. The production policy level of 25.8 million $\mathrm{m}^{3}$ would require an expenditure of approximately $\$ 39$ million for comparable silviculture work. For the 34 million $\mathrm{m}^{3}$ production policy level, approximately $\$ 55$ million would need to be spent on silviculture. To meet the target levels, more money needs to be allocated to silvicultural work. 
The above problems are compounded by the fact that the planting part of the regeneration program is not $100 \%$ successful but ranges from $30 \%$ survival for container stock to $60 \%$ survival for bare root stock after 5 years of growth (Heeney, 1977). Hearnden (1978), noted a number of technical problems in the regeneration effort as well as suggested that the regeneration efforts up to 1976 would not produce the high quality forest required by the forest production policy.

Heeney also indicated that the area not regenerated in northeastern and northwestern Ontario was greater than the figures might imply as the reforestation program in southern Ontario was increasing during the three year period of $1973 / 74$ to $1975 / 76$. The same trend is evident in $1979 / 80$ (Table 2) as ten percent more of the regeneration effort was applied to patented land than in previous years.

\section{Conclusions}

1. Every acre harvested is not being regenerated.

2. It is unlikely that two trees are being regenerated naturally or artificially for every one harvested.

3. The production policy is falling behind schedule.

4. Productive forest areas including backlog and future cuts must be identified.

5. Reed (1980b) states that "the OMNR is currently implementing an aggressive program"', which may alleviate the situation.

One must have faith in the future.

\section{References}

Armson, K. 1976. Forest management in Ontario, 1976. Ontario Ministry of Natural Resources. $171 \mathrm{p}$.

Hearnden, K. W. 1978. Growing the second forest in Ontario. Ontario Conference on Forest Regeneration, Kirkland Lake. 27. $p$.

Heeney, C. J. 1978. Regeneration in Ontario. Woodlands Section, Canadian Pulp and Paper Association, Montreal. (Pulp and Paper Canada 78(1): 29-32).

Legislature of Ontario Debates Official Report (Hansard) 1980. 3 Nov. 1980. p. 4026.

Ontario. Ministry of Natural Resources. 1980. Strategic land use plan, Northwestern Ontario. (Draft Copy) Kenora, Ont. 84 p. 1980. Proposed strategic land use plan. Northeastern Ontario. Sudbury, Ont. $106 \mathrm{p}$.

1974. Forest Management Branch; Division of Forests.

1972. Forest production policy in Ontario. OMNR, Division on Forests. $67 \mathrm{p}$.

Ontario Statistics (Ministry of Natural Resources) 1974 to 1979.

Reed, F. L. C. and Associates. 1980a. Forest management expenditures in Canada compared to taxes generated. Prepared for Canadian Pulp and Paper Assoc. as background material for the Canadian Forest Congress, Toronto, 1980. 86 p.

Reed, F. L. C. and Associates. 1980b. Recent reductions in the Canadian timber base. Prepared for Canadian Pulp and Paper Assoc. as background material for the Canadian Forest Congress, Toronto, 1980. 49 p.

Reed, F. L. C. and Associates. 1978. Forest management in Canada Vol. 1. Forest Management Institute. Infor. Report FMR-X-102.

\section{Important rappel pour les finissants de 1981 en science forestière}

Si vous avez obtenu un diplôme en science forestière cette année, vous devrez probablement prendre sous peu des décisions importantes au sujet de votre avenir. Vous devez gagner votre vie. Vous prévoyez peut-être vous marier et acheter une maison. Bien entendu, vous avez besoin d'une assurance vie.

L'Impériale, Compagnie d'Assurance-Vie administre le régime d'assurance vie de I'Institut Forestier du Canada et, à titre de membre de I'IFC, vous êtes admissible à une assurance vie à coût modique. Par exemple, jusqu'à l'âge de trente ans, vous ne devriez verser que $\$ 20$ de prime annuelle pour obtenir une protection de $\$ 10,000$ et tant que vous aurez moins de cinquante ans, votre protecttion d'assurance pourra s'élever jusqu'à $\$ 100,000$.

Et ce n'est pas tout! Le capital assuré serait augmenté de $50 \%$ si un sinistre survenait avant le 30 avril 1982. De plus, aucuns frais supplémentaires ne seront exigés pour cette protection supérieure, ce qui signifie que si, par exemple, une demande de règlement était faite en vertu d'une police de $\$ 50,000$, vous recevriez $\$ 75,000$.

Si vous désirez des renseignements supplémentaires concernant ce régime d'assurance vie avantageux, écrivez à l'Institut Forestier du Canada, C.P. 5000, Collège Macdonald (Québec) H9X 1 Co. 